\title{
Investigating the Changes in Physicochemical and Oxidative Properties of Different Brands of Sunflower Oil Sold in Market Before and After Frying
}

\author{
Dr. Shashikant Pardeshi* \\ * Food Analyst, DPHL, Jalgaon, Maharashtra
}

\begin{abstract}
Oils and fats for commercial frying applications can lead the changes caused by oxidation, polymerization, or hydrolysis during high-temperature processing. Deep frying is one method which involves submerging the food in hot oil. During oxidation can lead to the formation of potentially toxic oxidation products. This lipid per oxidation products generates that may be harmful to human health and it is necessary to monitoring of the frying oil quality degradation, therefore, is an important issue for both food frying operators and food control/regulatory agencies. In this study, The changes in the physicochemical properties of eight different brands of sunflower oils were analysed (before and after frying) using standard procedures of AOAC and AOCS. The experimental results obtained that,RI and specific gravity and colour were in the range of 1.4658-1.4720,0.9018-0.8848 and1.82-16.6 before and after frying. AV and PV were ranged between 0.22-0.54 in fresh oils,0.85-1.21in after frying and 2.4-4.1and 8.18$13.15 \mathrm{mg} \mathrm{KOH} / \mathrm{g}$ before and after frying oil while $\mathrm{SV}$ and $\mathrm{EV}$ were ranged between 189.98-193.12 and 189.62192.67 mg KOH/g oil in fresh oils and in between 198.68202.18 and 197.71-200.97mg $\mathrm{KOH} / \mathrm{g}$ oil in after frying oils respectively. $\mathrm{P}-\mathrm{AV}$ and TV were in the range of 3.95.01 and 8.79-13.21 in before frying while in case of after frying it is $9.16-13.15$ and $25.52-38.55 \mathrm{meq} / \mathrm{kg}$ respectively. In general, after frying, RI, colour,AV,PV,P-anisidine and totox values were found higher and deviates codex standards and specific gravity and iodine values are lower than as compared with safety limit. The results showed degradation in the physico-chemical properties of the vegetable cooking oil after frying.
\end{abstract}

Keywords:- Sunflower Oils, Frying, Physicochemical and Oxidative Characteristics.

\section{INTRODUCTION}

Edible vegetable oils are used in food, both in cooking and as supplements. During frying, oil or fat is exposed to air, water and heat. Therefore, thermal, oxidative, and hydrolytic decomposition of the oil may occur. Fats and oils are oxidized to form hydroperoxides, the primary oxidation products. These peroxides are extremely unstable and decompose via fission, dehydration, and formation of free radicals to form a variety of chemical products, such as alcohols, aldehydes, ketones, acids, dimers, trimers, polymers, and cyclic compounds [1-2].

The high frying temperatures, the presence of oxygen, moisture, trace elements and free radicals lead to thermooxidation reactions and oil breakdown. Consequently, volatile and non-volatile oxidative compounds are formed. These breakdown compounds affect the quality of frying oil and fried product. Foaming also occurs when products with high initial moisture content are fried. Repeated and continuous use of degraded oils compromises the quality of the food and pose a potential risk to human health and nutrition[3-4]. In frying technology, like in other fields, there is a continuous need for innovation in terms of process efficiency and product quality[5]. Thus, split frying and vacuum frying have been proposed to help reduce oil uptake by fried foods and oil breakdown during frying[6].

Frying causes complex physicochemical reactions such as starch gelatinization, protein denaturation, browning, crust formation, textural and flavor changes. These depend on either the frying process itself or the nature of the food or type of frying oil[7]. The popularity of fried foods has at no time been reported to decrease. This is certainly due to the smooth mouthfeel, distinct flavor, palatability, and aesthetic appeal of fried foods. Deep-fat frying is a simultaneous heat and mass transfer process. Frying oils are usually maintained at elevated temperatures ranging from 150 to $200^{\circ} \mathrm{C}$. The hot oil serves as a medium of heat transfer into the food, while the moisture migrates out and the oil is absorbed [8]. 


\section{LITERATURE REVIEW}

Atmospheric deep-fat frying is usually practiced. At high frying temperatures and in the presence of oxygen, thermo-oxidation and breakdown occur especially if the oil is polyunsaturated. These reactions lead to the formation of volatile and non-volatile oxidative compounds that affect the quality of frying oil and fried products. Foaming also occurs when products with high initial moisture content are fried. Repeated and continuous use of frying oils produces undesirable compounds that may compromise the quality of the food and pose a potential risk to human health and nutrition[9].

Frying temperature is high, the amount of fried oil, free fatty acids, polyvalent metal, and unsaturated fatty acids decrease the stability of the oil due to oxidation and the taste quality of the oil. Frying oil with high temperatures can degrade the effectiveness of antioxidants. Fried oil changes in the stability of the taste or quality of the oil by hydrolysis, oxidation, and polymerization. Tocopherols, essential amino acids, and fatty acids in the diet degraded during frying. Changes frying oil depends on factors like the freshness of the oil, frying conditions, the original quality of cooking oil, fried foods, types of frying, antioxidants, oxygen concentration[10].

Oils with higher amounts of PUFA are not stable to oxidation and the products fried using such oils have shorter shelf-life. PUFA oils quickly break down at frying temperatures to form gums. Some physical changes such as increased viscosity and foaming, color changes and decreased smoke-point, also occur. Also, a vast number of volatile compounds are formed during the frying process, depending on the nature of the oil used and the frying conditions employed. The volatiles cover different classes of compounds, like alkanes, alkenes, alcohols, saturated and unsaturated aldehydes/ ketones, and short chain fatty acids. These compounds are responsible for the distinctive pleasant odor and the unpleasant flavor of abused frying oil and can be used as markers of frying oil quality [12-14].During frying, several chemical reactions such as hydrolysis, oxidation, polymerization, fission and isomerization take place. The presence of oxygen, moisture, trace elements and free radicals at the high temperatures used in frying accelerate the breakdown process. These reactions change the oil from a medium that is almost pure triacylglycerol when fresh to one that contains literally thousands of different degradation compounds. These can compromise the texture, taste, flavor, and the overall perception of the fried product. Additionally, potential risk to human health and nutrition may arise [11].
Total FFA depends on the amount of water introduced into the frying medium by the food, the food composition, the frying temperature, the oil turnover time, and the accumulation of burnt food particles. Thus, heated and unheated oils must be monitored by means of analysis However; FFA only reflects hydrolytic changes, comprising only part of the complex degradation process that occurs during frying. FFA levels in frying oil increase with the number of frying cycles and are therefore used to monitor the quality of the frying oil[15-16]. The peroxide value is used to determine the level of oil damage. The peroxide value standard for vegetable oils that do not undergo rancidity should be well below10 meq/kg. Saponification value is a rough index of the molecular weight of the fat or oil. The smaller the sv higher molecular weight. It also shows the magnitude of the amount of alkali required to convert the amount of fat or oil to be soap. It can be used for checking the purity of fats or oils [17].

Moreover, poly-unsaturated oils have reduced stability at elevated temperatures; unsaturated fatty acids easily react with oxygen to form peroxides [18]. Peroxide value is useful as an indicator of oxidation at the initial stages; however, it is not related to the frying duration, but to the formation and breakdown of oxidation products. Peroxides are unstable and decompose at frying temperature. They may even increase after the sample is taken from the fryer. Hence, it is generally not a very reliable parameter to determine deterioration of frying oil quality [19-20].

The choice of the frying oil is important for a heat transfer medium during frying. Therefore, the oil must be reasonably stable at high temperature and must stay stable for multiple heating cycles. The fried products absorb some of the oil during frying, this requires the oil to maintain high oxidative stability throughout the life of the product and remain nutritious [21].

The aim of present study was to evaluate the effect of frying on the physical and chemical properties such as Colour, specific gravity, RI, Viscosity, Acid, Peroxide, Iodine and Saponification, Ester ,P-anisindine and Totox values for different brands of sunflower oil sold in market Before and After Frying and to assess whether these oils could be re-used or not. 


\section{MATERIALS AND METHODS}

Edible oil samples refined sunflower (fortune)(rsf),refined sunflower (sundrop life)(rssl) and refined sunflower oils (emami) (rse),refined sunflower (sweekar)(rssk),refined sunflower (dhara)(rsd),refined sunflower oils (freedom)(rsfd), refined sunflower (swaad)(rssw) and refined sunflower (Silver drop)(rssd) samples before and after frying were purchased from some food supply markets in Jalgaon city of Maharashtra, India and home kitchen uses. All these oils were in different forms of packaging while some in poly packs (HDPE), others were in tetra packs, plastic bottles, cans, pet and glass bottles of 1 litre and 5 litres. Most of the brands have mentioned nutritional values, green vegetarian $\log 0$ and best before 6 and 9 months, free from argemone oils on their packs. In this study, cooking oil samples of different type's oil were subjected to controlled heating and frying in the laboratory at $180{ }^{\circ} \mathrm{C}$ to $200{ }^{\circ} \mathrm{C}$ for $6 \mathrm{hr}$. Colour, refractive index, The acid value, peroxide value, iodine value and saponification value, $\mathrm{p}$-anisindine value and totox value of edible oil before and after frying were measured according to the AOCS and AOAC [23-26]. All the chemicals reagents and glassware used in this analytical work are analytical grade. Deionised water was used for preparation and dilutions of standard solutions. Nitric acid $\left(\mathrm{HNO}_{3}\right)$ and sulphuric acid $\left(\mathrm{H}_{2} \mathrm{SO}_{4}\right)$ reagents were used for cleaning of glassware and for digestion of the samples. Representative edible oil samples were used for analysis. Chloroform, potassium iodide (KI), glacial acetic acid, and sodium thiosulphate were used for estimation of peroxide value. Hydrochloric acid $(\mathrm{HCl})$, sodium hydroxide $(\mathrm{NaOH})$, ethanol, and phenolphthalein indicators were used for estimation of acid value and saponification value, respectively; carbon tetra chloride, potassium iodide, sodium thiosulphate and Wijs reagent were used for estimation of iodine value.

\subsection{Experimental procedures [23-30]}

\subsubsection{Determination of physical properties}

\subsubsection{Determination of colour}

Lovibond tintometer was used to measure the colour of samples as described in AOCS method 13e-92 (AOCS, 1989a).Colour was reported in terms of Lovibond units as:Colour reading $=(\mathrm{a} Y+5 \mathrm{~b} R)$ Where, $\mathrm{a}=$ sum total of the various yellow slides $(\mathrm{Y})$ used

$\mathrm{b}=$ sum total of the various red $(\mathrm{R})$ slides used, $\mathrm{Y}+5 \mathrm{R}$ is the mode of expressing the colour of oils

\subsubsection{Determination of Refractive index}

The refractive index (RI) of the oil sample was measured using Abbe refractometer following IS 548 (IS 548, 2015a) method.

\subsubsection{Determination of Specific Gravity of the Oil}

The specific gravity of the oil samples was determined using a $25 \mathrm{ml}$ specific gravity bottle. The specific gravity bottle was weighed empty and then filled with the oil sample up to the mark on the bottle. The bottle with oil sample was weighed again. The weight of the empty bottle was subtracted from the total weight of the bottle and oil sample. The weight of the empty bottle was divided by the total weight of the bottle and oil to obtain the weight of the oil sample. The weight of the oil sample was then divided by the weight of an equal volume of water to get the specific gravity of the oil sample.

\subsubsection{Determination of Chemical properties}

\subsubsection{Determination of Acid Value of the Oil}

Acid value was measured by titration with sodium hydroxide according to the American Oil Chemists' Society (AOCS) method Cd 8-53 (AOCS, 1989b).

\subsubsection{Saponification value:}

The saponification value (SV) of the sample was obtained by following IS 548 method (IS 548, 2015b).

\subsubsection{Method for determination of ester value}

The ester value is the 'mg' of $\mathrm{KOH}$ required to react with glycerol/ glycerin after saponify $1 \mathrm{~g}$ of oil sample. Ester value is calculated by the following relation

Ester Value $=$ Saponification Value - Acid Value

\subsubsection{Iodine value:}

The iodine value (IV) of the sample was measured using IS 548 (IS 548, 2015c).

\subsubsection{Peroxide value:}

The acetic acid-chloroform method of the AOCS (Method Ca 5a-40) was used for determination of the peroxide value (PV) (AOCS, 1989c).

\subsubsection{6 p-anisidine Value:}

The p-anisidine value was obtained using a spectrophotometer (UV 1700, Shimadzu Corporation) according to the AOCS method Cd 18-90 (AOCS, 1989d).

\subsubsection{Determination of Totox value}

The totox (i.e. total oxidation products) value was calculated by AOCS Ccl3e-92 method. The totox value was calculated as: Totox value $=\mathrm{TV}=(2 \mathrm{xPV})+\mathrm{AV}$ 


\section{EXPERIMENTAL RESULTS OF PHYSICOCHEMICAL CHARACTERISTICS OF DIFFERENT BRANDS OF} SOYABEAN OIL BEFORE AND AFTER FRYING

\begin{tabular}{|c|c|c|c|c|c|c|c|c|c|c|c|c|c|}
\hline $\begin{array}{c}\text { Propertie } \\
\text { s }\end{array}$ & Rsf & Rss1 & Rse & Rssk & Rsd & Rsfd & Rssw & Rssd & Total & Mean & SD & $\mathbf{C V}$ & SEM \\
\hline & \multicolumn{13}{|c|}{ Before frying } \\
\hline Colour & 4.82 & 6.60 & 8.20 & 5.80 & 7.40 & 4.80 & 6.80 & 7.5 & 51.92 & 6.49 & 0.44 & 6.71 & 0.25 \\
\hline RI & $\begin{array}{c}1.466 \\
9\end{array}$ & $\begin{array}{c}1.465 \\
8\end{array}$ & $\begin{array}{c}1.467 \\
8\end{array}$ & $\begin{array}{c}1.469 \\
0\end{array}$ & $\begin{array}{c}1.467 \\
4\end{array}$ & $\begin{array}{c}1.466 \\
8\end{array}$ & $\begin{array}{c}1.468 \\
4\end{array}$ & $\begin{array}{c}1.467 \\
8\end{array}$ & 11.74 & 1.4675 & 0.24 & $\begin{array}{c}16.3 \\
5\end{array}$ & 0.14 \\
\hline Sp.G. & $\begin{array}{c}0.902 \\
6\end{array}$ & $\begin{array}{c}0.904 \\
0\end{array}$ & $\begin{array}{c}0.903 \\
8\end{array}$ & $\begin{array}{c}0.904 \\
8\end{array}$ & $\begin{array}{c}0.902 \\
4\end{array}$ & $\begin{array}{c}0.903 \\
2\end{array}$ & $\begin{array}{c}0.901 \\
8\end{array}$ & $\begin{array}{c}0.903 \\
4\end{array}$ & 7.226 & 0.9033 & 0.001 & 0.14 & 6.94 \\
\hline $\mathrm{AV}$ & 0.54 & 0.33 & 0.22 & 0.44 & 0.23 & 0.36 & 0.45 & 0.34 & 2.91 & 0.36 & 0.04 & 9.82 & 0.02 \\
\hline PV & 3.0 & 3.2 & 3.91 & 2.4 & 3.60 & 2.96 & 3.9 & 4.1 & 27.07 & 3.38 & 0.28 & 8.33 & 0.16 \\
\hline IV & $\begin{array}{c}127.6 \\
8 \\
\end{array}$ & $\begin{array}{c}128.2 \\
4\end{array}$ & $\begin{array}{c}130.1 \\
2\end{array}$ & $\begin{array}{c}131.2 \\
8\end{array}$ & $\begin{array}{c}132.8 \\
6\end{array}$ & $\begin{array}{c}129.8 \\
2\end{array}$ & $\begin{array}{c}128.8 \\
8\end{array}$ & $\begin{array}{c}130.2 \\
6\end{array}$ & $\begin{array}{c}1039.1 \\
4\end{array}$ & 129.89 & 0.29 & 6.22 & 0.17 \\
\hline SV & $\begin{array}{c}191.7 \\
8\end{array}$ & $\begin{array}{c}190.5 \\
6\end{array}$ & $\begin{array}{c}192.6 \\
4\end{array}$ & $\begin{array}{c}191.7 \\
8\end{array}$ & $\begin{array}{c}192.4 \\
6\end{array}$ & $\begin{array}{c}189.9 \\
8\end{array}$ & $\begin{array}{c}193.1 \\
2\end{array}$ & $\begin{array}{c}191.6 \\
5\end{array}$ & $\begin{array}{c}1533.9 \\
7\end{array}$ & 191.75 & 0.5 & 0.26 & 0.19 \\
\hline EV & $\begin{array}{c}191.2 \\
4\end{array}$ & $\begin{array}{c}190.2 \\
3\end{array}$ & $\begin{array}{c}192.4 \\
2\end{array}$ & $\begin{array}{c}191.3 \\
4\end{array}$ & $\begin{array}{c}192.2 \\
3\end{array}$ & $\begin{array}{c}189.6 \\
2\end{array}$ & $\begin{array}{c}192.6 \\
7\end{array}$ & $\begin{array}{c}191.3 \\
1\end{array}$ & $\begin{array}{c}1531.0 \\
6\end{array}$ & 191.38 & .45 & .24 & .26 \\
\hline P-AV & 4.12 & 4.21 & 4.60 & 3.99 & 4.15 & 3.90 & 4.21 & 5.01 & 34.19 & 4.27 & 0.16 & 3.64 & 0.09 \\
\hline \multirow[t]{2}{*}{ Totox } & 10.12 & 10.61 & 12.42 & 8.79 & 11.35 & 9.82 & 12.01 & 13.21 & 88.33 & 11.04 & 0.26 & 2.41 & 0.15 \\
\hline & \multicolumn{13}{|c|}{ After frying } \\
\hline Colour & 7.14 & 13.4 & 16.6 & 11.9 & 14.80 & 8.40 & 12.5 & 14.0 & 98.74 & 12.34 & 0.3 & 2.47 & 0.17 \\
\hline RI & $\begin{array}{c}1.469 \\
4\end{array}$ & $\begin{array}{c}1.468 \\
0\end{array}$ & $\begin{array}{c}1.470 \\
0\end{array}$ & $\begin{array}{c}1.472 \\
0\end{array}$ & $\begin{array}{c}1.470 \\
0\end{array}$ & $\begin{array}{c}1.469 \\
4\end{array}$ & $\begin{array}{c}1.471 \\
5\end{array}$ & $\begin{array}{c}1.471 \\
0\end{array}$ & $\begin{array}{c}11.761 \\
3\end{array}$ & $\begin{array}{c}1.4701 \\
6\end{array}$ & $\begin{array}{c}0.000 \\
2\end{array}$ & 0.02 & $\begin{array}{c}0.000 \\
1\end{array}$ \\
\hline Sp.G & $\begin{array}{c}0.879 \\
0\end{array}$ & $\begin{array}{c}0.884 \\
8\end{array}$ & $\begin{array}{c}0.862 \\
4\end{array}$ & $\begin{array}{c}0.875 \\
6\end{array}$ & $\begin{array}{c}0.881 \\
2\end{array}$ & $\begin{array}{c}0.863 \\
8\end{array}$ & $\begin{array}{c}0.872 \\
4\end{array}$ & $\begin{array}{c}0.872 \\
8\end{array}$ & 6.992 & 0.874 & 0.05 & 5.69 & 2.89 \\
\hline $\mathrm{AV}$ & 1.21 & 0.86 & 0.85 & 0.97 & 1.01 & 0.97 & 1.21 & 1.0 & 8.08 & 1.01 & 0.1 & 9.97 & 0.06 \\
\hline PV & 8.18 & 9.52 & 9.5 & 9.58 & 12.7 & 9.6 & 12.2 & 12.7 & 83.98 & 10.49 & 0.33 & 3.12 & 0.19 \\
\hline IV & $\begin{array}{c}121.2 \\
8\end{array}$ & $\begin{array}{c}122.4 \\
8 \\
\end{array}$ & $\begin{array}{c}124.8 \\
4\end{array}$ & $\begin{array}{c}125.3 \\
8 \\
\end{array}$ & $\begin{array}{c}125.9 \\
8 \\
\end{array}$ & $\begin{array}{c}121.4 \\
8\end{array}$ & $\begin{array}{c}120.4 \\
6\end{array}$ & $\begin{array}{c}122.6 \\
2\end{array}$ & 984.52 & 123.07 & 0.79 & 0.64 & 0.46 \\
\hline SV & $\begin{array}{c}199.2 \\
8 \\
\end{array}$ & $\begin{array}{c}198.8 \\
8 \\
\end{array}$ & $\begin{array}{c}201.5 \\
6\end{array}$ & $\begin{array}{c}200.1 \\
2 \\
\end{array}$ & $\begin{array}{c}201.5 \\
8\end{array}$ & $\begin{array}{c}198.6 \\
8 \\
\end{array}$ & $\begin{array}{c}202.1 \\
8\end{array}$ & $\begin{array}{c}200.1 \\
4\end{array}$ & $\begin{array}{c}1602.4 \\
2\end{array}$ & & 0.36 & 0.18 & 0.21 \\
\hline EV & $\begin{array}{c}198.0 \\
7 \\
\end{array}$ & $\begin{array}{c}198.0 \\
2\end{array}$ & $\begin{array}{c}200.7 \\
1\end{array}$ & $\begin{array}{c}199.1 \\
5\end{array}$ & $\begin{array}{c}200.5 \\
7\end{array}$ & $\begin{array}{c}197.7 \\
1\end{array}$ & $\begin{array}{c}200.9 \\
7\end{array}$ & $\begin{array}{c}199.1 \\
4\end{array}$ & $\begin{array}{c}1594.3 \\
4\end{array}$ & 199.29 & 0.26 & 0.13 & 0.15 \\
\hline P-AV & 9.16 & 10.23 & 11.34 & 9.12 & 11.15 & 10.12 & 12.17 & 13.15 & 86.44 & 10.81 & 0.02 & 0.15 & 0.01 \\
\hline Totox & 25.52 & 29.27 & 30.34 & 28.28 & 36.55 & 29.32 & 36.57 & 38.55 & 254.4 & 31.8 & 0.53 & 1.66 & 0.31 \\
\hline
\end{tabular}

Table1:- Physicochemical characteristics of soyabean oil at room temperature before frying.

\begin{tabular}{|c|c|c|c|c|c|}
\hline Sr.no & Test & Before frying & After frying & $\begin{array}{c}\text { Codex Alimentarius } \\
\text { commission standard }\end{array}$ & FSSAI \\
\hline 1 & RI & $1.4658-1.4690$ & $1.4680-1.4720$ & -- & -- \\
\hline 2 & Specific gravity & $0.9018-0.9048$ & 0.8624 to 0.8848 & $0.899-0.920$ & -- \\
\hline 3 & Colour & $1.82-8.2$ & $7.14-16.6$ & $0.91-0.93$ & -- \\
\hline 4 & Acid value & $0.22-0.54$ & $0.85-1.21 \mathrm{mg} \mathrm{KOHg}-1$ & $0.6 \mathrm{mg} \mathrm{KOHg}-1$ & $0.5-6.0 \mathrm{mg} \mathrm{KOHg}-1$ \\
\hline 5 & IV gI $/ 100 \mathrm{~g}$ & $127.68-132.86$ & $120.46-125.98 \mathrm{gI}_{2} / 100 \mathrm{~g}$ & --- & -- \\
\hline 6 & SV mg KOHg-1 & $189.98-193.12$ & $198.68-202.18$ & --- & -- \\
\hline 7 & EV mg KOHg-1 & $189.62-192.67$ & $197.71-200.97$ & --- & $1-10 \mathrm{meq} \mathrm{O} 2 / \mathrm{kg}$ \\
\hline 8 & Peroxide value & $2.4-4.1$ & $8.18-12.7 \mathrm{meq} \mathrm{O} / \mathrm{kg}$ & $10.00 \mathrm{meq} \mathrm{O} / \mathrm{kg}$ & -- \\
\hline 9 & P-anisidine value & $3.9-5.01$ & $9.16-13.15 \mathrm{meq} \mathrm{O} / \mathrm{kg}$ & $20 \mathrm{MeqO}_{2 / \mathrm{Kg}}$ & -- \\
\hline 10 & Totox value & $8.79-13.21$ & $25.52-38.55 \mathrm{meq} \mathrm{O} 2 / \mathrm{kg}$ & $26 \mathrm{Meq}_{2 / \mathrm{Kg}}$ & \\
\hline
\end{tabular}

Table 2:- Test results of frying oils and codex standards

Statistical Analysis:

The data obtained from the experimental measurements and accuracy of different parameters for different varieties of oils have been analysed and the Statistical parameter like standard deviation, coefficient of variance and standard mean error were calculated for AV,IV,SV and EV for different brands of oils before and after frying. All the experiment was carried out in triplicate and the results are presented as the mean $\pm \mathrm{SD}, \mathrm{CV}, \pm$ SEM. Accuracy and descriptive Statistics of different oils from different parts of India as shown in figure1to3. 

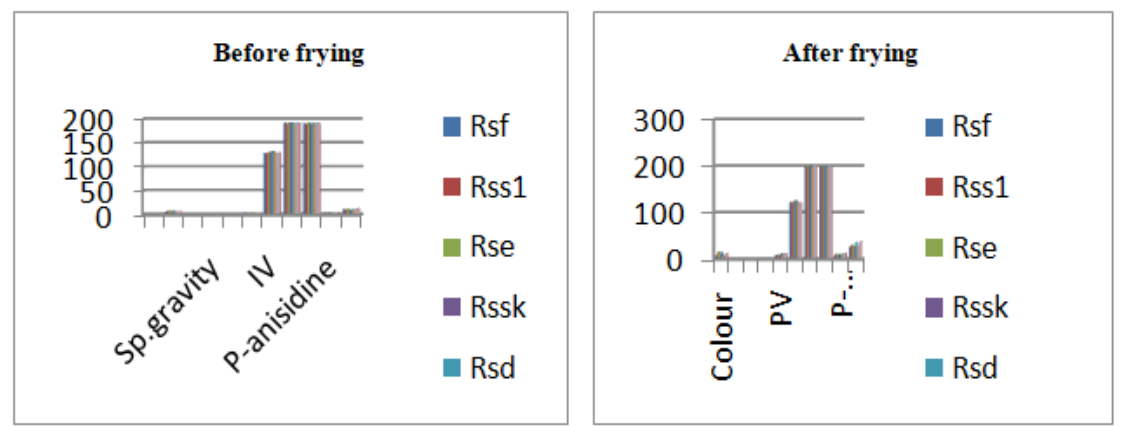

Fig 1-2:- Plot of different characteristics of different edible vegetable against the obtained experimental data before and after frying

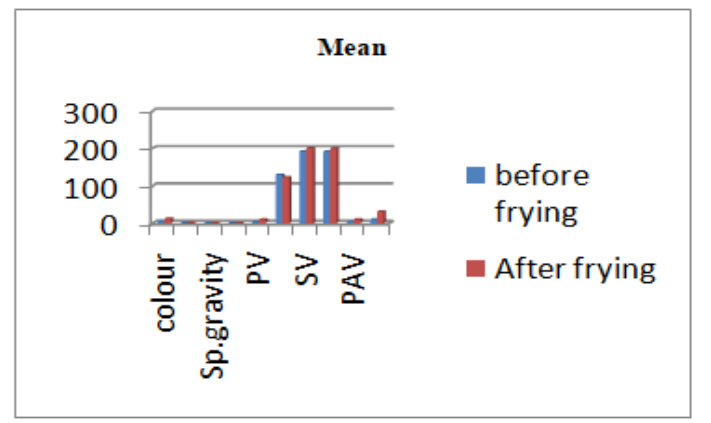

Fig 3:- Accuracy and descriptive Statistics of different brands of sunflower edible vegetable oils from different parts of India.

\section{RESULTS AND DISCUSSION}

All results determined are shown in Table 1-2. When the different brands of sunflower oil samples obtained from the local markets have been examined before and after frying for physiochemical parameters such as RI, colour, specific gravity, viscosity, AV, IV, PV,SV, EV, P-anisidine and totox values were used to monitor deterioration of fried oil while it was used to authenticate oil samples. The obtained results of the different brands of sunflower frying oil samples are compared to each other before frying and after frying are illustrated in Tables 1-2 and figures 1-3. In this study, It is seen that, the results showed that in the range of $1.4658-1.4720( \pm 0.0-0.24)$ in case of RI which are exceeded, In case of specific gravity, it is in the range of 0.9018-0.8884( $\pm 0.0-.005)$ which are decreased as compared with codex safety standards. Colour in the yellow units in the range of $1.82-16.6( \pm 0.44-0.3)$ while in case of acid value, it is seen in range 0.22-1.21( $\pm 0.04-0.1)$ which are increased. In case of IV,127.68-125.98( $\pm 0.29-0.79)$ which are gradually decreased as the result of destruction of double bonds in after frying, the result was not in this expectation, while in case of PV it is in the range of 2.4-12.7 \pm 0.28 0.33 which are higher as compared with codex limit of 10 meq $/ \mathrm{kg}$ in after frying, The P-anisidine value are in between $3.9-13.15( \pm 0.16-0.02)$ which are exceeded with the limit of $20 \mathrm{meq} / \mathrm{kg}$ in case of after frying, The totox value are in the range of $8.79-38.55( \pm 0.26-0.53)$ which are highest and higher than the top limit of $26 \mathrm{meq} / \mathrm{kg}$ and deviates codex standards and SV and Ester value are in the range of 189.98$202.18( \pm 0.5-0.36) \quad$ and $189.62-200.97( \pm 0.45-0.26)$ respectively. The AV, PV,P-Anisidine and totox values which were significantly higher compared to the Codex Alimentarius Commission standards in after frying. Peroxide values of $8.18-12.7( \pm 0.33) \mathrm{meq} \mathrm{O} / \mathrm{kg}$ after frying deviated from the Codex standard value of $10 \mathrm{meq} \mathrm{O} / \mathrm{kg}$, this may be explained by splitting of hydro peroxides which form during the first stage of the oxidation. Acid values in the range of $0.85-1.21( \pm 0.1) \mathrm{mg} \mathrm{KOH} / \mathrm{g}$ after frying, which are significantly higher compared to the Codex Alimentarius Commission standards. In case of P-anisidine value, it is seen that ,after frying $9.16-13.15 \mathrm{mg} / \mathrm{KOH}$ which deviates the codex limit of $20 \mathrm{meq} / \mathrm{kgand}$ in case of totox value ,it is $25.52-38.55 \mathrm{meq} / \mathrm{kg}$ after frying increased with codex limit of $26 \mathrm{meq} / \mathrm{kg}$. In general, It can be noticed that, after frying, viscosities, AV,PV,P-anisidine and totox values were found higher and specific gravity and iodine values are lower than as compared with safety limit. The results showed degradation in the physico-chemical properties of the vegetable cooking oil after frying. These results undesirable odour might be due to the effect of high frying temperature causing destruction of some glycerides.

\section{CONCLUSION}

The experimental results of sunflower oil before and after frying are investigated. It is clear from the obtained results that, after frying, RI, colour, viscosities, AV,PV,Panisidine and totox values were found higher and specific gravity and iodine values are lower than as compared with safety limit. The results showed degradation in the physicochemical properties of the vegetable cooking oil after frying. AV,PV, P-anisidine and totox values of edible oil increased after frying compared with that before frying (might be due to the effect of high frying temperature causing destruction of some glycerides). The study concluded that most of the vegetable oils are susceptible to oxidation at higher temperature. It is important to add antioxidants such as vitamin $\mathrm{E}$ as preservatives in vegetable oils to slow down the rate of oxidation. 


\section{REFERENCES}

[1]. White PJ Methods for measuring changes in deep-fat frying oils. Food Technology, 1991; 45:75-79.

[2]. Melton SL, Jafar S, Sykes D and MK Trigiano Review of stability measurements for frying oils and fried food flavor. Ibid, 1994; 71: 1301-1308.

[3]. Andrikopoulos NK, Boskou G, Dedoussis GVZ, Chiou A, Tzamtzis VA \& Papathanasiou A (2003) Quality assessment of frying oils and fats from 63 restaurants in Athens, Greece. Food Service Technology. 3(2), 4959.

[4]. Kita A (2014) The effect of frying on fat uptake and texture of fried potato products*. European Journal of Lipid Science and Technology. 116(6), 735-740.

[5]. Blumenthal MM \& Stier RF (1991) Optimization of deep-fat frying operations. Trends in Food Science \& Technology. 2, 144-148.

[6]. Moreira RG (2014) Vacuum frying versus conventional frying - An overview*. European Journal of Lipid Science and Technology. 116(6), 723734.

[7]. Marrikar JMN, Ghazali HM, Long K \& Lai OM (2003) Lard uptake and its detection in selected food products deep-fried in lard. Food Resource International. 36, 1047 - 1060.

[8]. Moreira RG (2014) Vacuum frying versus conventional frying - An overview*. European Journal of Lipid Science and Technology. 116(6), 723734.

[9]. Andrikopoulos NK, Boskou G, Dedoussis GVZ, Chiou A, Tzamtzis VA \& Papathanasiou A (2003) Quality assessment of frying oils and fats from 63 restaurants in Athens, Greece. Food Service Technology. 3(2), 4959.

[10]. Syafruddin Ilyas(2016) ,Peroxides and Saponification Value to Some Packaging of Palm Oil after Frying Repeatedly , International Journal of PharmTech Research, ISSN: 0974-4304, 9(12): 560-564.

[11]. [11]. Gotoh et al(2011), Gotoh N,Miyake S, Takei H,Sasaki K, okudas,Ishinaga $M$ and wada S.,Simple method for measuring the peroxide value in a coloured lipid, food analytical methods 4(4),525-30

[12]. Setiowaty et al (2000), Quantitative determination of peroxide value in thermally oxidized palm oilein by fourier transform infrared spectroscopy phytochemical analysis, 11(2),74-78.

[13]. Weisshaar (2014), Quality control of used deep-frying oil, European journal of lipid science and Tecnology, 116(6), 716-722.

[14]. Naghshineh et al (2000),Naghshineh and Mirhosseini ,Effects of frying condition on physic-chemical properties of palm-olein-olive oil blends, journal of agriculture and environment 8(3-4),175-178.

[15]. Choe et al (2007), Choe E, Min DB. Chemistry of deep-fat frying oils. Journal of Food Science, 72(5) R (77-88), doi:10.1111/j.1750-3841.2007.00352.x.

[16]. Bou et al,(2012), Quality assessment of frying fats and fried snacks during continuous deep fat frying at different large scale producers food control 27(1),254267.
[17]. [17]Adel et al (2018),Adel Imhemed Alajtal, Fatima Emhemed Sherami, Mohamed Atiga Elbagermi. Acid, Peroxide, Ester and Saponification Values for Some Vegetable Oils Before and After Frying. AASCIT Journal of Materials. Vol. 4(2): 43-47.

[18]. Che-Man YB and WR Wan-Hussin Comparison of the frying performance of refined, bleached and deodorized palm olein and coconut oil. Journal of Food Lipids, 1998; 5: 197-210.

[19]. Hau LB, Young PK and LS Hwang Quality assessment of oils during heating and frying. Journal of Chinese Agricultural Chemical Society, 1986; 24: 397-405.

[20]. Warner K and M Gupta Frying quality and stability of low and ultra low linoleic acid soybean oils. Journal of American Oil Chemists Society, 2003; 80: 275-280.

[21]. Alireza S, Tan CP, Hamed M \& Che Man YB (2010a) Effect of frying process on fatty acid composition and iodine value of selected vegetable oils and their blends. International Food Research Journal. 17(2), 295-302.

[22]. Nawar WW Lipids in Food chemistry, 3rd Ed. O. R. Fennema (Ed.), Marcel Dekker, New York, 1996: 225319.

[23]. ISI Hand book of food Analysis (part III) 1984 page 67/ IUPAC2.201 (1979) I.S, 548 (Part-1)-1964 method of sampling and test for oils and fats/ISO 66011996 Determination of acid value and acidity.

[24]. A.O.A.C, Official Method 920.160-Saponfication Number of Oils and Fats/IUPAC 2.202 I.S.I Hand Book of Food Analysis (Part XIII 1984), A.O.A.C, 17th edition, 2000.

[25]. A.O.A.C, Official Method 965.33 Peroxide value in oils and fats/Pearson's composition and analysis of food, 17th edition, pp. 641, 2000.

[26]. AOCS, Official Method Cd 18-90: p-Anisidine Value. American Oil Chemists Society Sampling and Analysis of Commercial Fats and oils (1997c).

[27]. DGHS,(2012)., Directorate General of Health Services, Manual of Methods of Analysis of Foods (Oils and Fats), Food Safety standards authority of India ( FSSAI), Ministry of Health and Family Welfare, Government of India, New Delhi.

[28]. IS 548 (Part I). (2015a) Determination of refractive index, Method. No.10:pp 35

[29]. IS 548 (Part I). (2015b) Determination of saponification value. Method. No.15: pp 50.

[30]. IS 548 (Part I). (2015c) Determination of iodine value. Method. No.14: pp 47. 